\title{
Use of bauxite from active Iranian mines for the removal of fluoride from drinking water
}

\author{
Mohammad Malakootian ${ }^{1,2^{*}}$, Marzie Javdan $^{2}$, Farnaz Iranmanesh $^{1}$ \\ ${ }^{1}$ Environmental Health Engineering Research Center, Kerman University of Medical Sciences, Kerman, Iran \\ ${ }^{2}$ Department of Environmental Health, School of Public Health, Kerman University of Medical Sciences, Kerman, Iran
}

\begin{abstract}
Background: Fluoride plays an important role in bone and dentin mineralization; however, excess fluoride intake is harmful to mankind.

Methods: This study evaluated the performance of bauxite from active Iranian mines in removing fluoride from drinking water. The effects of $\mathrm{pH}$, contact time, adsorbent dose, and fluoride concentration on defluoridation and removal efficiency were determined. Kinetics and adsorption isotherms were studied. Fluoride levels were measured using SPADNS. Data analysis was performed using SPSS16. Results: Bauxite from the Jajarm mine had the lowest adsorbency $(20 \mathrm{~g} / \mathrm{L})$ and required the shortest contact time (90 minutes) to reach equilibrium compared with the ore from bauxite mines evaluated in another study which had greater efficiency rates in removing fluoride from drinking water (58.15\%). The fluoride removal efficiency rates of the other bauxite mines were as follows: Mendon $>$ Sadrabad $>$ Khidabas $>$ Khezri $>$ Shahbalaghi $>$ Tash $>$ Biglar. Bauxite from Shomal-e Yazd, Hasanabad, and Shahid Nilchian mines could not achieve the required efficiency to remove fluoride from drinking water without initial preparation and modification. The removal efficiency rates of actual samples were much lower than the synthetic samples because of confounding factors.

Conclusion: As a result of the low cost and abundant availability of bauxite and the fact that its use does not require a particular expertise or sophisticated technology, the removal efficiency of this adsorbent can be increased to desirable levels through the use of corrective methods such as heating, acidifying, particle crushing, or the mixing of two or more removal systems.

Keywords: Fluoride, Iran, drinking water, kinetics

Citation: Malakootian M, Javdan M, Iranmanesh F. Use of bauxite from active Iranian mines for the removal of fluoride from drinking water. Environmental Health Engineering and Management Journal 2017; 4(4): 217-224. doi: 10.15171/EHEM.2017.30.
\end{abstract}

\section{Article History:}

Received: 12 June 2017

Accepted: 21 August 2017

ePublished: 14 September 2017

\section{Introduction}

Fluoride occurs naturally in mineral deposits and natural water systems (1). Since groundwater is a major source of human exposure to fluoride $(2,3)$, determining the amount of fluoride present in drinking water is an important factor in human health. The treatment of groundwater resources is often the only disinfection performed on drinking water; fluoridation and defluoridation rarely occur (4). Fluoride has been classified as a water pollutant by the World Health Organization (WHO). The presence of fluoride in drinking water, dependent upon concentration (5) and duration of continuous absorption (2), can be either helpful or harmful to humans. Maintaining a fluoride concentration of about $1 \mathrm{mg} / \mathrm{L}$ can prevent skeletal and dental problems, especially in children $(2,6)$. However, the intake of excessive fluoride can cause serious concerns for public health (7).

Fluorosis is one of the most important public health issues around the world (5). Dental and skeletal fluorosis is irreversible, and there is no treatment for it yet. The only remedy is prevention, which is possible by maintaining safe limits of fluoride intake. Following the WHO guidelines, many countries have reported $1.5 \mathrm{mg} / \mathrm{L}$ as the maximum contaminant level. Many epidemiologists have indicated in their reports, however, that there is the possibility of adverse effects with long-term exposure to fluoride, even where consumption is at the permissible limit $(8,9)$. Global estimates suggest that over 70 million people suffer from fluorosis (10). Fluoride concentrations in the drinking water of large parts of the world are higher than allowed by the WHO guidelines (11). It is estimated that more than 200 million people worldwide use drinking water that has a fluoride concentration higher than set standards (2). The presence of high levels of fluoride in groundwater is a global problem and is found in various locations in Africa, Asia, and America (9). 
Mesdaghinia et al studied the monitoring of fluoride levels in the groundwater of Iran (4). Their study showed that in various regions of Iran, especially Bushehr province and parts of Hormozgan, Khorasan-e Razavi, Fars, and Yazd provinces, fluoride levels in groundwater were higher than standard levels (4). A study conducted in 2012 by Haghighat et al showed that fluoride concentrations in the drinking water of Dashtestan and Borazjan from Bushehr port functions, Hormozgan (Bandar Abbas, Bandare Lenghe, Qeshm), Yazd (Ardakan), Hamedan, Tehran, Kerman (Shahrbabak, Kuhbanan), Khorasan-e Razavi, South Khorasan, Semnan, Zabol, and Zahedan were higher than set standards (11).

The effects of excess fluoride on teeth and bones have been documented (12). Research on the removal of fluoride from water in order to prevent dental and skeletal fluorosis is improving around the world.

Methods such as coagulation, chemical precipitation, surface adsorption, electrochemical and membrane processes, and ion exchange are used to remove excess fluoride from water (13). The high costs and complexity of application of many of these methods prohibit their use in developing countries and low-income areas (14). There is a growing tendency to use local materials and low-cost methods for the removal of fluoride from water (15). Removing fluoride from water by surface adsorption is known as the ideal method in small communities. In recent years, the use of low-cost adsorbents to remove fluoride from water has been investigated. Hydroxyapatite, calcite, fluorspar and quartz (16), fly ash (17), red mud (18), and bentonite (19) are some such adsorbents. Bauxite is a native and available mineral consisting of aluminum hydroxides with minor and variable amounts of silica, iron oxide, titanium oxide, and alumina silicate (20). Many studies have investigated using bauxite to remove pollutants from water, such as Bhakat et al in India (21), Baral et al in India (22), and Debasish et al in Korea (23) which used bauxite to remove arsenic and chromium (VI) and chromium, respectively. In Tanzania, Thole used bauxite to remove fluoride from water (24). Sajidu et al In 2008 in India, used raw bauxite for the removal of fluoride from water (25). Atasoy et al in Turkey (26), Lavecchia et al in Italy (20), and Malakootian et al in Iran used bauxite to remove fluoride from water (3). Some areas of Iran have high fluoride concentrations; however, prior to this study, the efficiency of bauxite from Iranian mines in fluoride removal had not been studied. Thus, the current study evaluated the efficiency of activated bauxite from ore mined in Iran in removing fluoride from aqueous solutions.

\section{Methods}

This experimental study was conducted on synthetic and actual samples in the Environmental Health Engineering Research Center, Kerman University of Medical Sciences, from May to November of 2013. Actual samples were collected from drinking water from the Kuhbanan region in northwestern Kerman province $\left(31^{\circ} 24^{\prime} 37^{\prime \prime} \mathrm{N}\right.$, $56^{\circ} 16^{\prime} 57^{\prime \prime} \mathrm{E}$ ) (Figure 1).

Previous studies reported that fluoride concentrations in the water resources of this region ranged from 2.3-5.4 $\mathrm{mg} / \mathrm{L}$ (27). First, the chemical quality of actual samples was determined. Bauxite, used as adsorbent in this study, was prepared from bauxite mines that were active in Iran until 2011 (Jajarm mine located in north Khorasan; Shomal-e Yazd and Sadrabad mines located in Yazd; Shahblaghi mine located in Damavand; Hassanabad and Biglar mines located in Qazvin; Mendon mine located in Kohgeloye and Bovair Ahmad; Shahid Nilchian mine in Chaharmahal and Bakhtiari; Khezri and Khidbas mines in South Khorasan; and Tash mine in Semnan province). Initially, stones were crushed, ground, and sieved to obtain $<250 \mu \mathrm{m}$ size (mesh 60). The resultant bauxite powder was washed with deionized water, dried in an oven at $200^{\circ} \mathrm{C}$ in an open-air chamber muffle furnace for 2 hours, and cooled at room temperature. Samples were stored in a desiccator. X-ray fraction (XRF) and x-ray diffraction (XRD) were used to determine the chemical composition and the phases in the bauxite powder samples. XRD and XRF analyses were done using the Philips X'PERT device in Iran Mineral Processing Research Center. Stock solution was prepared by dissolving $0.221 \mathrm{mg}$ sodium fluoride $(\mathrm{NaF})$ in $1000 \mathrm{~mL}$ deionized water ( $1 \mathrm{~mL}=100 \mu \mathrm{g} / \mathrm{F})$, and experimental solutions of the required concentrations were prepared from this solution. Fluoride was measured using the SPADNS method and spectrophotometry (wavelength $=570 \mathrm{~nm}$ ). All analysis methods were taken from the "Standard Methods for Examination of Water and Wastewater", 20th edition (28). Absorption tests were used to determine equilibrium time, adsorption kinetics, and optimal conditions $(\mathrm{pH}$, contact time, fluoride concentration, and amount of adsorbent), and the adsorption isotherm models were studied. Absorption experiments were used to determine equilibrium time, synthetic absorption, and optimum conditions and to study the adsorption isotherm models. The operational parameters were $\mathrm{pH}$ values (3-34); initial

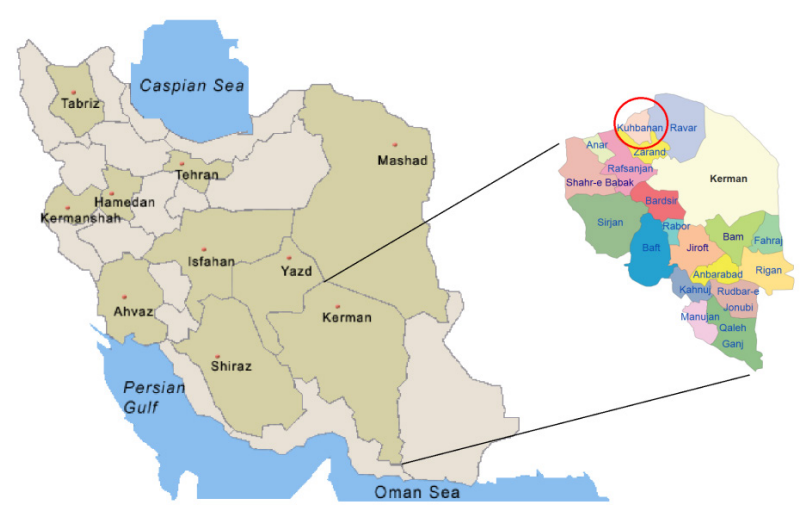

Figure 1. Geographical map of Kuhbanan region in northwestern Kerman province $\left(31^{\circ} 24^{\prime} 37^{\prime \prime} \mathrm{N}, 56^{\circ} 16^{\prime} 57^{\prime \prime} \mathrm{E}\right)$. 
fluoride concentrations $(2,4,6 \mathrm{mg} / \mathrm{L})$; dosages of bauxite $(2,5,34,15,20,25,30 \mathrm{~g} / \mathrm{L})$; contact times (5-240 minutes). Tests were then performed under optimal conditions on actual samples, and removal efficiency was measured. The $\mathrm{pH}$ value of the samples was set to $0.1 \mathrm{~N}$ by $\mathrm{H}_{2} \mathrm{SO}_{4}$ and $\mathrm{NaOH}$. The $\mathrm{pH}$ was measured by a microprocessor pH meter (model 211 Hanna). Deionized water was used in the preparation of all solutions and in all analyses. Removal efficiency (E\%) and adsorption capacity $\left(\mathrm{q}_{e}\right.$ $\mathrm{mg} / \mathrm{L})$ were calculated using equations 1 and 2 :

$\mathrm{E}=\left[\left(\mathrm{C}_{\mathrm{i}}-\mathrm{C}_{\mathrm{e}}\right) / \mathrm{C}_{\mathrm{i}}\right] \times 100$

$\mathrm{q}_{\mathrm{e}}=\left[\left(\mathrm{C}_{\mathrm{i}}-\mathrm{C}_{\mathrm{e}}\right) \mathrm{V}\right] / \mathrm{m}$

where $C_{i}$ and $C_{e}$ are the initial and final concentrations of fluoride in solution $(\mathrm{mg} / \mathrm{L})$, respectively, $V$ is the volume of solution (L), and $m$ is mass of the adsorbent $(\mathrm{g})$.

Langmuir and Freundlich isotherm models were investigated to study the adsorption isotherms. Data analysis was performed using SPSS software version 16 .

\section{Results}

Composite sampling was done 3 times from the Kuhbanan water resource. Analysis of the samples was expressed as the average of three replicates. The commonly occurring cations and anions present in the Kuhbanan drinking water sample were found in $\mathrm{mg} / \mathrm{L}$ as $\mathrm{NO}_{3}^{-}$(5.6), $\mathrm{SO}_{4}{ }^{2-}(139), \mathrm{Cl}^{-}$ (126), Total solid (711), $\mathrm{Ca}^{2+}(83), \mathrm{K}^{+}(1.9), \mathrm{Mg}(49), \mathrm{Na}^{+}$ (95), $\mathrm{F}^{-}(2.3-2.7), \mathrm{Fe}^{3+}(<0.05), \mathrm{Al}^{3+}(<0.01), \mathrm{pH}(6.9-7.66)$, and temperature $\left(25-27^{\circ} \mathrm{C}\right)$. Sajidu et al examined the effects of bauxite on water quality after fluoride removal in the villages of southern Malawi in order to measure the amount of fluoride and fluoride removal by bauxite. In this study, a slight increase in aluminium and silicon contents and the $\mathrm{pH}$ of the water after bauxite was used; however, the amounts were less than the WHO standards (15). On this basis, there was no need to measure $\mathrm{Al}$ and Fe contents.

The names of each mine and the chemical analyses of ore from each using XRF and XRD are presented in Table 1.
The greatest constituents in all mines were $\mathrm{Al}_{2} \mathrm{O}_{3}, \mathrm{Fe}_{2} \mathrm{O}_{3}$, $\mathrm{SiO}_{2}$, and $\mathrm{TiO}_{2}$. The main phases of most mines were diaspore, anatase and boehmite.

The maximum fluoride removal efficiency rate achieved using bauxite from the studied mines and the optimal amount of bauxite, contact time, and $\mathrm{pH}$ for both the synthetic and actual water samples from Kuhbanan are given in Table 2.

The results regarding the pseudo first order and pseudo second order kinetics for initial fluoride concentrations (2, 4, $6 \mathrm{mg})$ are presented in Table 3.

The Langmuir and Freundlich isotherm parameters for the adsorption of fluoride using $5 \mathrm{~g}$ of activated bauxite from ore mined in Iran, $\mathrm{pH}=7$, and initial fluoride concentrations of 2, 4, and $6 \mathrm{mg} / \mathrm{L}$ are given in Table 4 .

\section{Discussion}

The results showed that the ore from all active bauxite mines in Iran (with the exception of Nilchian, Hasanabad, and Shomal-e Yazd mines) had the required qualities for fluoride removal from drinking water samples and could achieve much lower concentrations than the WHO guidelines (from $2.74 \mathrm{mg}$ to less than $1.5 \mathrm{mg}$ ) without any preparation or modification. The bauxite particles from Jajarm, Tash, Mendon, and Sadrabad mines proved more efficient than that from other mines in adsorbing fluoride from drinking water. The differences in performance are associated with several factors, such as the composition of the adsorbent.

Table 1 shows that the ore from all studied bauxite mines have aluminium, silicon, titanium, and iron oxide (the four main elements of bauxite). The fluoride removal efficiency is correlated with the percentage of $\mathrm{AL}_{2} \mathrm{O}_{3}$ and $\mathrm{Fe}_{2} \mathrm{O}_{3}$ compounds. Percentages of silicon oxide $\left(\mathrm{SiO}_{2}\right)$ and titanium oxide $\left(\mathrm{TiO}_{2}\right)$ in each of the 11 studied mines were higher than the percentages reported in other studies. Gomoro et al in Ethiopia used 3 lateritic soils including red gullale soil (RGS), yellow gullale soil (YGS), and ambo soil

Table 1. Chemical analysis of Iranian active bauxite mines by XRF and XRD

\begin{tabular}{|c|c|c|c|c|c|c|c|c|c|}
\hline \multirow{2}{*}{ Name of mine } & \multirow{2}{*}{$\begin{array}{l}\text { XRD pattern of the bauxite ore mines } \\
\text { The main minerals of bauxite }\end{array}$} & \multicolumn{8}{|c|}{ Percentage of chemical compounds of Bauxite by XRF } \\
\hline & & $\mathrm{P}_{2} \mathrm{O}_{5}$ & $\mathrm{~K}_{2} \mathrm{O}$ & MgO & $\mathrm{CaO}$ & $\mathrm{Fe}_{2} \mathrm{O}_{3}$ & $\mathrm{Al}_{2} \mathrm{O}_{3}$ & $\mathrm{TiO}_{2}$ & $\mathrm{SiO}_{2}$ \\
\hline Tash & Diaspore Kaolinite Chamosite & 0.05 & 0.52 & 0.48 & 0.66 & 20.60 & 49.31 & 3.98 & 10.39 \\
\hline Nilchian & Diaspor-Boehemite-Anatase-Kaolinit & 0.05 & 0.12 & 0.13 & 0.42 & 1.07 & 53.90 & 2.78 & 30.51 \\
\hline Mendon & Boehemite-Hematie-Kailinite & 0.06 & 0.05 & 0.17 & 0.29 & 19.51 & 53.64 & 2.48 & 12.43 \\
\hline Jajarm & Diaspore- Anatase -Chamosite & 0.09 & 0.22 & 0.69 & 1.53 & 21.06 & 51.05 & 5.56 & 9.82 \\
\hline Biglar & Dioaspore-Anatase-Hematite-Chlorite & 0.16 & 0.65 & 0.12 & 0.44 & 38.50 & 24.96 & 6.18 & 11.87 \\
\hline Khidbas & Boehemite-Hematite-Kaolinite & 0.07 & 0.25 & 0.33 & 0.44 & 20.97 & 40.04 & 2.43 & 24.00 \\
\hline Sadrabad & Diaspore-Hematite-Cholorite-Anatas & 0.10 & 0.03 & 2.35 & 0.52 & 24.77 & 45.77 & 5.87 & 10.20 \\
\hline Hassanabad & Diaspore-Anatase & 0.12 & 0.99 & 0.04 & 0.45 & 1.89 & 59.90 & 11.60 & 9.31 \\
\hline Shahbalaghy & Kaolinite-Chamosite-Anatase & 0.09 & $<0.03$ & 0.67 & 0.29 & 39.80 & 21.85 & 3.79 & 16.97 \\
\hline Kaezri & Boehemite-Kaolinite & 0.08 & 0.20 & 0.19 & 0.30 & 17.67 & 44.36 & 3.76 & 13.28 \\
\hline Shomal-e-Yazd & Diaspore-Hematite-Dolomite-Quartz & 0.09 & 1.00 & 3.35 & 6.62 & 19.93 & 34.38 & 4.74 & 17.27 \\
\hline
\end{tabular}


Table 2. Maximum efficiency of fluoride removal by using bauxite of studied mines with optimal amounts of bauxite, contact time and pH for synthetic and water samples of Kuhbanan

\begin{tabular}{|c|c|c|c|c|c|c|}
\hline Entry & Name of mine & $\begin{array}{l}\text { Contact time } \\
(\min )\end{array}$ & $\mathrm{pH}$ & $\begin{array}{c}\text { Fluoride removal from Kuhbanan } \\
\text { drinking water }(2.74 \mathrm{mg} / \mathrm{L})\end{array}$ & $\begin{array}{l}\text { Efficiency of fluoride removal from } \\
\text { synthetic samples ( } 2 \mathrm{mg} / \mathrm{L})\end{array}$ & $\begin{array}{c}\text { Adsorbent } \\
\text { dose (g) }\end{array}$ \\
\hline 1 & Tash & 120 & 7 & 61.67 & 70.39 & 25 \\
\hline 2 & Nilchian & 180 & 6 & 30.19 & 60.16 & 35 \\
\hline 3 & Mendon & 120 & 7 & 56.64 & 85.75 & 20 \\
\hline 4 & Jajarm & 90 & 7 & 58.15 & 93.12 & 20 \\
\hline 5 & Biglar & 180 & 6 & 49.31 & 66.47 & 25 \\
\hline 6 & Khidbas & 180 & 6 & 52.69 & 80.41 & 30 \\
\hline 7 & Sadrabad & 180 & 7 & 53.21 & 84.69 & 25 \\
\hline 8 & Hassanabad & 180 & 6 & 36.05 & 62.72 & 30 \\
\hline 9 & Shahbalaghy & 180 & 6 & 46.05 & 77.17 & 25 \\
\hline 10 & Kaezri & 180 & 7 & 50.87 & 82.91 & 35 \\
\hline 11 & Shomal-e-Yazd & 180 & 7 & 36.68 & 64.74 & 30 \\
\hline
\end{tabular}

Table 3. The results of investigation of pseudo first and pseudo second order of kinetics for initial fluoride concentrations (2, 4,6 mg)

\begin{tabular}{|c|c|c|c|c|c|c|c|c|}
\hline \multirow{2}{*}{ Entry } & \multirow{2}{*}{ Name of mine } & \multirow{2}{*}{$\begin{array}{l}\text { Fluoride concentrations } \\
\mathrm{mg} / \mathrm{L}\end{array}$} & \multicolumn{3}{|c|}{ First class synthetic } & \multicolumn{3}{|c|}{ Second class synthetic } \\
\hline & & & $\mathrm{K}_{1}$ & $q_{e}$ & $\mathbf{R}^{2}$ & $\mathrm{~K}_{2}$ & $q_{e}$ & $\mathbf{R}^{2}$ \\
\hline \multirow[t]{3}{*}{1} & Tash & 2 & 0.023 & 0.562 & 0.976 & 0.148 & 0.303 & 0.985 \\
\hline & & 4 & 0.023 & 0.707 & 0.956 & 0.062 & 0.501 & 0.967 \\
\hline & & 6 & 0.016 & 0.664 & 0.959 & 0.086 & 0.494 & 0.979 \\
\hline \multirow[t]{3}{*}{2} & Nilchian & 2 & 0.013 & 0.540 & 0.975 & 0.292 & 0.053 & 0.911 \\
\hline & & 4 & 0.018 & 0.652 & 0.998 & 0.419 & 0.047 & 0.933 \\
\hline & & 6 & 0.018 & 0.648 & 0.950 & 0.466 & 0.049 & 0.933 \\
\hline \multirow[t]{3}{*}{3} & Mendon & 2 & 0.023 & 0.553 & 0.942 & 0.218 & 0.347 & 0.991 \\
\hline & & 4 & 0.027 & 0.762 & 0.988 & 0.116 & 0.613 & 0.988 \\
\hline & & 6 & 0.034 & 0.810 & 0.940 & 0.156 & 0.667 & 0.989 \\
\hline \multirow[t]{3}{*}{4} & Jajarm & 2 & 0.018 & 0.567 & 0.958 & 0.138 & 0.339 & 0.984 \\
\hline & & 4 & 0.032 & 0.748 & 0.982 & 0.090 & 0.543 & 0.983 \\
\hline & & 6 & 0.018 & 0.816 & 0.872 & 0.025 & 0.754 & 0.906 \\
\hline \multirow[t]{3}{*}{5} & Biglar & 2 & 0.009 & 0.484 & 0.950 & 0.089 & 0.254 & 0.929 \\
\hline & & 4 & 0.011 & 0.634 & 0.979 & 0.043 & 0.447 & 0.919 \\
\hline & & 6 & 0.006 & 0.710 & 0.984 & 0.027 & 0.580 & 0.887 \\
\hline \multirow[t]{3}{*}{6} & Khidbas & 2 & 0.016 & 0.549 & 0.962 & 0.063 & 0.320 & 0.940 \\
\hline & & 4 & 0.013 & 0.752 & 0.973 & 0.025 & 0.683 & 0.842 \\
\hline & & 6 & 0.013 & 0.816 & 0.968 & 0.024 & 0.803 & 0.866 \\
\hline \multirow[t]{3}{*}{7} & Sadrabad & 2 & 0.009 & 0.538 & 0.936 & 0.078 & 0.331 & 0.939 \\
\hline & & 4 & 0.011 & 0.692 & 0.975 & 0.043 & 0.559 & 0.948 \\
\hline & & 6 & 0.013 & 0.800 & 0.987 & 0.035 & 0.734 & 0.954 \\
\hline \multirow[t]{3}{*}{8} & Hassanabad & 2 & 0.009 & 0.478 & 0.975 & 0.063 & 0.248 & 0.883 \\
\hline & & 4 & 0.009 & 0.648 & 0.985 & 0.025 & 0.484 & 0.851 \\
\hline & & 6 & 0.006 & 0.653 & 0.965 & 0.029 & 0.501 & 0.878 \\
\hline \multirow[t]{3}{*}{9} & Shahbalaghy & 2 & 0.011 & 0.502 & 0.886 & 0.222 & 0.296 & 0.991 \\
\hline & & 4 & 0.011 & 0.653 & 0.909 & 0.105 & 0.563 & 0.990 \\
\hline & & 6 & 0.020 & 0.669 & 0.949 & 0.114 & 0.656 & 0.996 \\
\hline \multirow[t]{3}{*}{10} & Khezri & 2 & 0.011 & 0.521 & 0.977 & 0.062 & 0.292 & 0.940 \\
\hline & & 4 & 0.009 & 0.661 & 0.982 & 0.034 & 0.509 & 0.928 \\
\hline & & 6 & 0.009 & 0.714 & 0.950 & 0.029 & 0.623 & 0.932 \\
\hline \multirow[t]{3}{*}{11} & Shomal-e-Yazd & 2 & 0.004 & 0.511 & 0.780 & 0.146 & 0.223 & 0.949 \\
\hline & & 4 & 0.004 & 0.644 & 0.784 & 0.154 & 0.352 & 0.989 \\
\hline & & 6 & 0.004 & 0.747 & 0.888 & 0.042 & 0.494 & 0.891 \\
\hline
\end{tabular}


Table 4. Langmuir and Freundlich isotherm ( $5 \mathrm{~g} / \mathrm{L}$ bauxite, $\mathrm{pH}=7$, initial fluoride concentrations 2,4 and $6 \mathrm{mg})$

\begin{tabular}{|c|c|c|c|c|c|c|c|}
\hline \multirow{2}{*}{ Entry } & \multirow{2}{*}{ Name of mine } & \multicolumn{3}{|c|}{ Freundlich isotherm } & \multicolumn{3}{|c|}{ Langmuir isotherm } \\
\hline & & $n$ & $\mathbf{k}_{f}$ & $\mathbf{R}^{2}$ & $q_{m}$ & $k_{\perp}$ & $\mathbf{R}^{2}$ \\
\hline 1 & Tash & 3.484 & 0.616 & 0.884 & 0.504 & 2.319 & 0.991 \\
\hline 2 & Nilchian & 2.906 & 0.540 & 0.980 & 0.470 & 1.090 & 0.999 \\
\hline 3 & Mendon & 3.225 & 0.732 & 0.908 & 0.712 & 2.900 & 0.997 \\
\hline 4 & Jajarm & 2.801 & 0.677 & 0.994 & 0.718 & 1.500 & 0.998 \\
\hline 5 & Biglar & 1.766 & 0.526 & 0.981 & 0.750 & 0.438 & 0.995 \\
\hline 6 & Khidbas & 1.795 & 0.623 & 0.915 & 0.899 & 0.645 & 0.955 \\
\hline 7 & Sadrabad & 1.992 & 0.513 & 0.998 & 0.581 & 0.603 & 0.982 \\
\hline 8 & Hassanabad & 1.992 & 0.513 & 0.917 & 0.581 & 0.603 & 0.968 \\
\hline 9 & Shahbalaghy & 1.988 & 0.664 & 0.873 & 0.859 & 0.926 & 0.959 \\
\hline 10 & Kaezri & 1.751 & 0.563 & 0.977 & 0.841 & 0.476 & 0.992 \\
\hline 11 & Shomal-e-Yazd & 2.016 & 0.521 & 0.993 & 0.663 & 0.485 & 0.964 \\
\hline
\end{tabular}

(AS) to remove fluoride from drinking water (9). Under oxidative conditions and as a result of the weathering of rocks, this soil loses silica. The main component of this soil depends on lateritic phase. The last step is the formation of bauxite. Maximum fluoride removal using $2 \mathrm{~g} / \mathrm{L}$ of RGS soil was $32.32 \%$. The findings of a more complex fluoride formation with RGS soil could be due to the presence of high levels of alumina $\left(\mathrm{Al}_{2} \mathrm{O}_{3}\right)(9)$.

In a study conducted in Tanzania in 2009, Peter used two types of kaolinite and bauxite-rich soil to remove fluoride (29). His results showed that soil rich in bauxite had a higher adsorption capacity than soil rich in kaolinite. He identified the chemical and mineral composition of soils as reasons for different removal rates. Soil chemical analyses revealed that soil rich in bauxite had a large amount of aluminum oxide compared to soil rich in kaolinite. Peter introduced aluminum oxide as a good adsorbent for fluoride removal due to the $\mathrm{Al}$ and $\mathrm{F}$ ions reaction (29). XRF analyses of ore from all bauxite mines achieved results similar to those of Altundoğan and Tümen who used bauxite in phosphate removal (30), Ayoob et al who used arsenic in bauxite removal (31), Sujana et al (8), Sajidu et al (25), and Malakootian et al (32) who used bauxite in fluoride removal. However, there are differences in the percentages of major bauxite compositions among all studies. Gomoro et al indicated that changes in the various formation stages of bauxite are reasons for different percentages of bauxite ore compounds in various locations (9). According to the results of the presented XRD patterns, all mines included the same minerals, such as bauxite, diaspore $(\mathrm{AlOOH})$, anatase $\left(\mathrm{TiO}_{2}\right)$, and quartz $\left(\mathrm{SiO}_{2}\right)$. Diaspore is from the aluminum hydroxide family, and this can be the main factor in removing fluoride with bauxite. High amounts of anatase and kaolinite in some mines can cause decreasing fluoride removal efficiency. Peter attributed the low fluoride removal efficiency using kaolinite to the high content of $\mathrm{SiO}_{2}$ (50.60\%) (29). Gomoro et al found that anatase and quartz rarely have a good adsorption capacity for fluoride removal (9).

With the ore from all bauxite mines in Iran, with a fixed amount of adsorbent ( $5 \mathrm{~g} / \mathrm{L})$, initial concentrations of fluoride $(2,4$, and $6 \mathrm{mg} / \mathrm{L})$, and over time, the removal efficiency increased to the maximum extent. However, it did not increase for a longer time. After equilibrium time, the repulsive forces between the pollutant on the adsorbent and contaminants in the solution prevented contact between the pollutants and the adsorbent. The shortest time to reach equilibrium was 90 minutes, achieved using bauxite from the Jajarm mine; the longest time to reach equilibrium was 180 minutes, achieved using bauxite from Khidbas, Khezri, Sadrabad, Shomale-Yazd, Biglar, Hasanabad, Nilchian, Mendon, Tash, and Shahbalaghi mines. The equilibrium time for bauxite from Tash mine was 120 minutes. In all cases, equilibrium time was independent of the initial concentration of fluoride. Peter used soils rich in bauxite and kaolinite to remove fluoride from water with high concentrations of fluoride. He achieved a range of 90 to 180 minutes as the maximum time to achieve efficiency of fluoride removal by both soils. Peter expressed that saturation of the ion-exchange positions explained achieving equilibrium over time (29). Sujana et al used bauxite to remove fluoride. Equilibrium time was calculated at 120 minutes for concentrations of 4 and 12 mg-F (8). Atasoy et al used raw and modified bauxite in fluoride removal and reached equilibrium after $3 \mathrm{hr}$. They found that the removal rate was fast at first, because all the absorption positions were empty and free fluoride ions were available (26). Evaluations of the effect of time on removal efficiency in the mentioned studies revealed results similar to those of the present study.

One factor that has a significant impact on the adsorption process is $\mathrm{pH}$. Basically, bauxite is a mixture of iron, aluminum, silica, titanium oxide, and hydroxide. When bauxite is hydrated at neutral $\mathrm{pH}$, a net positive or negative charge will be formed which is able to adsorb the fluoride anion. According to the results for bauxite from all 11 mines, the highest fluoride removal efficiency was observed at neutral $\mathrm{pH}$, and the lowest fluoride removal efficiency was observed at acidic and alkaline $\mathrm{pHs}$. The reduction in removal efficiency at $\mathrm{pH}<5$ could 
be attributed to the formation of poor hydrofluoric acid (HF). The reduction in efficiency in alkaline $\mathrm{pHs}$ could be due to competition between hydroxide ions $\left(\mathrm{OH}^{-}\right)$and fluoride ions $\left(\mathrm{F}^{-}\right)$in the absorption process. Shrivastava and Vani reviewed fluoride removal methods and found that the maximum fluoride absorption by alumina takes place in $\mathrm{pH}$ 5-7. They justified reduction efficiency at $\mathrm{pHs}$ less than 5 and greater than 7 with these two reasons: 1 ) At $\mathrm{pH}<5$, activated alumina is insoluble in water, and that leads to the loss of surface absorption; and 2) at $\mathrm{pH}$ $>7$, silicate and hydroxide have a stronger bond with the positions of absorption toward fluoride ions (33). These results concur with those of Sujana et al $(\mathrm{pH}=6.4)(8)$, Malakootian et el $(\mathrm{pH}=7)(34-36)$, and Sajidu et al $(\mathrm{pH}=$ 7) (15). At acidic and alkaline pHs, they showed the same trend.

Initial fluoride concentration is the most effective factor for fluoride ion transfer from the liquid phase to a solid phase adsorbent (37). The results showed that removal efficiency rates are higher in low concentrations of fluoride. By using fixed amounts of all bauxite samples, increasing the fluoride concentration from 2 to $6 \mathrm{mg} / \mathrm{L}$ increased the absorption capacity, but decreased the removal efficiency. A study by Atasoy et al showed that increasing the fluoride concentration from 1 to $10 \mathrm{mg} / \mathrm{L}$ reduced the removal efficiency from $66 \%$ to $36 \%$ (26). Lv et al used doublemodified hydroxides with polycarbonate, aluminum, and manganese in fluoride removal. By increasing the fluoride concentration from 20 to $200 \mathrm{mg} / \mathrm{L}$ (in a fixed amount of adsorbent), the residual fluoride was changed from 0.4 to $50 \mathrm{mg} / \mathrm{L}$. This result showed that the fluoride removal efficiency increased when the initial concentration of fluoride was decreased. The results of the mentioned studies were consistent with the results of the current study (38).

The results showed that by increasing amount of bauxite in all studied samples, the removal efficiency was increased, but the absorption capacity was decreased. Efficiency was almost constant with the addition of higher absorption. The maximum adsorption efficiency was $46.58 \%$, obtained using $2 \mathrm{~g} / \mathrm{L}$ of bauxite from the Sadrabad mine in $6 \mathrm{mg} / / \mathrm{L}$ of fluoride concentration. In similar conditions, when bauxite was increased to $25 \mathrm{~g} / \mathrm{L}$, the adsorption efficiency was $75.31 \%$. Increasing the amount of adsorbent made more active positions available for fluoride ions, but the removal efficiency did not show any dramatic increase for values higher than $25 \mathrm{gr} / \mathrm{L}$; in this amount only a limited amount of free fluoride ions remained. A study was conducted in Iran in 2011 by Malakootian et al to remove fluoride using regenerated spent bleaching earth. In this study, increasing the amount of adsorbent from 10 to $20 \mathrm{~g} / \mathrm{L}$ (concentration of fluoride $=2.5 \mathrm{mg} / \mathrm{L}$ ) increased removal efficiency from $66.41 \%$ to $74.01 \%$ (34). In India, Mohapatra et al used mineral oxides to remove fluoride. Similar behavior was observed with increased amounts of adsorbent (39).

In this study, fluoride removal using bauxite from the Sadrabad, Shahid Nilchian, Biglar, Khidbas, Hassanabad, and Khezri mines and using pseudo first order kinetics with a correlation coefficient greater than 0.950 showed better results than pseudo second order kinetics. The results of this study were consistent with those of other similar studies, such as Mohapatra et al (39), Das et al (40), and Sujana et al (8).

Fluoride removal using bauxite from the Shomal-e-Yazd, Tash, Mendon, Jajarm, and Shahbalaghi mines and using pseudo second order kinetics with a correlation coefficient greater than 0.984 showed better results than the pseudo first order kinetics. Thole (24) and Tor et al (41) found similar results. Analysis of the data regarding fluoride absorption on bauxite particles by isotherm showed that using bauxite from the Jajarm, Khidbas, Khezri, Shahid Nilchian, Mendon, Hassanabad, Biglar, Shahbalaghi, and Tash mines with a correlation coefficient greater than 0.955 , fluoride absorption obeyed the Langmuir adsorption isotherm. Sujana et al, Malakootian et al, and Das et al used bauxite as a fluoride adsorbent, and their experimental data was better described by the Langmuir absorption model $(8,34,40)$. These mentioned studies are consistent with this study.

Fluoride absorption by bauxite from the Sadrabad and Shomal-e Yazd mines with a correlation coefficient greater than 0.993 obeyed the Freundlich adsorption isotherm. Lavecchia et al (20) and Wang et al (42) obtained similar results. In this study, $20 \mathrm{~g} / \mathrm{L}$ of bauxite from the Jajarm and Mendon mines, $25 \mathrm{~g} / \mathrm{L}$ of bauxite from the Sadrabad, Biglar, Shahbalaghi and Tash mines, $30 \mathrm{~g} / \mathrm{L}$ of bauxite from the Hassanabad, Khidbas, and Shomal-e Yazd mines, and $35 \mathrm{~g} / \mathrm{L}$ of bauxite from the Khezri and Shahid Nilchian mines was added to the drinking water of Kuhbanan as the actual sample. Under these conditions and with no change to the $\mathrm{pH}$ of the water, fluoride concentrations changed from $2.74 \mathrm{mg} / \mathrm{L}$ to $1.15,1.14,1.28,1.42,1.48,1.48,1.75$, $1.30,1.74,1.35$, and $1.91 \mathrm{mg} / \mathrm{L}$, respectively. Generally, under the same conditions, the removal efficiency is less in actual samples than in synthetic samples. The presence of interfering ions in the actual samples (e.g., nitrate, sulfate, chloride) compete with fluoride to adsorb the iron and aluminum of the bauxite, resulting in a decrease in the removal efficiency of the actual sample. Sujana et al used bauxite to remove fluoride from groundwater (8). At $\mathrm{pH}=6$, increasing the sulfate, nitrate, and phosphate concentrations $(0-20 \mathrm{mg} / \mathrm{L})$ in solution caused a reduction in fluoride removal, and increasing the number of carbonate ions had a negligible effect on absorption (43). The absorption rate was lower in actual samples with normal $\mathrm{pH}$ values than in synthetic samples. In addition to interfering anions, water $\mathrm{pH}$ can cause a reduction. Das et al reported water $\mathrm{pH}$ as a reason for the reduction in absorption efficiency using activated titanium rich 
bauxite in the groundwater samples (40). According to the results, bauxite from the mines of Jajarm, Mendon, Sadrabad, Khezri, Khidbas, Shahbalaghi, Tash, and Biglar performed as needed to reach the WHO guidelines $(<1.5 \mathrm{mg} / \mathrm{L})$ to remove fluoride from actual (Kuhbanan drinking water with $2.74 \mathrm{mg} / \mathrm{L}$ fluoride concentration) and synthetic samples $(2,4$, and $6 \mathrm{mg} / \mathrm{L}$ concentrations of fluoride) with no initial preparation and as a raw material; however, the residual concentration of fluoride in the drinking water samples after using bauxite from the Hassanabad, Shahid Nilchian, and Shomal-e Yazd mines was greater than the WHO guidelines $(>1.5 \mathrm{mg} / \mathrm{L})$. The highest removal efficiency obtained using bauxite was seen at the Jajarm mine and equaled $93.12 \%$ for synthetic samples and $58.15 \%$ for actual samples from Kuhbanan. The use of the following methods is suggested to increase the fluoride removal efficiency, it is suggested that raw bauxite be improved by milling it to nanometer-sized particles, a high sorbent be used in actual samples, or the contact time with adsorbent be increased, and bauxite be modified using acid or heat.

\section{Conclusion}

Bauxite from the Jajarm mine had a higher removal efficiency $(58.15 \%)$ than the other studied mines. The removal efficiency rates of the other mines were as follows: Jajarm > Mendon > Sadrabad > Khidabas > Khezri $>$ Shahbolaghi $>$ Tash $>$ Biglar. Bauxite from the Shomal-e Yazd, Hasanabad, and Shahid Nilchian mines were not sufficiently efficient without initial preparation and modification. Although the removal efficiency in actual samples is much lower than that in synthetic samples, its low cost, abundant availability, and no need for expertise and sophisticated technology are beneficial. The removal efficiency of this adsorbent can be increased to the desirable level using corrective methods such as heating, acidifying, particle crushing, and the mixing of two or more removal systems.

\section{Acknowledgements}

This study extracted from a master's thesis conducted at the Environmental Health Engineering Research Center. It was sponsored by the Vice-Chancellor for Research and Technology of Kerman University of Medical Sciences. The author would like to express his gratitude for all the assistance provided by this University and to Iran's Mineral Processing Research Center which cooperated on the XRD and XRF analyses of bauxite ore mines and to all others involved in the realization of this study.

\section{Ethical issues}

The author hereby certifies that all data collected during the study is as stated in the manuscript, and no data from the study has been or will be published separately elsewhere.

\section{Competing interests}

The author declares that he has no competing interests.

\section{Authors' contributions}

The author contributed and is involved in the suggestion of the problem, design of experiments, data collection, and article approval.

\section{References}

1. Chen N, Zhang Z, Feng C, Sugiura N, Li M, Chen R. Fluoride removal from water by granular ceramic adsorption. J Colloid Interface Sci 2010; 348(2): 579-84. doi: 10.1016/j. jcis.2010.04.048.

2. Garmes H, Persin F, Sandeaux J, Pourcelly G, Mountadar M. Defluoridation of groundwater by a hybrid process combining adsorption and Donnan dialysis. Desalination 2002; 145(1): 287-91. doi: 10.1016/S0011-9164(02)00424-1.

3. Malakootian M, Javdan M, Iranmanesh F. Fluorid removal study from aqueous solutions using Jajarm bauxite: Case study on Koohbanan water. Fluoride 2015; 48(2): 113-122.

4. Mesdaghinia A, Vaghefi KA, Montazeri A, Mohebbi MR, Saeedi R. Monitoring of fluoride in groundwater resources of Iran. Bull Environ Contam Toxicol 2010; 84(4): 432-7. doi: 10.1007/s00128-010-9950-y.

5. Nie Y, Hu C, Kong C. Enhanced fluoride adsorption using Al (III) modified calcium hydroxyapatite. J Hazard Mater 2012; 233-234: 194-9. doi: 10.1016/j.jhazmat.2012.07.020.

6. Thole B, Mtalo F, Masamba W. Groundwater Defluoridation with Raw Bauxite, Gypsum, Magnesite, and Their Composites. Clean Soil Air Water 2012; 40(11): 1222-8. doi: 10.1002/clen.201100111.

7. Nagendra Rao CR. Fluoride and Environment-a Review; 2003 Dec 15-17; Department of Geography, University of Madras and Faculty of Environmental Studies, York University, Chennai; 2003.

8. Sujana MG, Anand S. Fluoride removal studies from contaminated ground water by using bauxite. Desalination 2011; 267(2-3): 222-7. doi: 10.1016/j.desal.2010.09.030.

9. Ayoob S, Gupta AK. Fluoride in Drinking Water: A Review on the Status and Stress Effects. Crit Rev Environ Sci Technol 2006; 36(6): 433-87.

10. Malakootian M, Fatehizadeh A, Yousefi N, Ahmadian M, Moosazadeh M. Fluoride removal using regenerated spent bleaching earth (RSBE) from groundwater: case study on Kuhbonan water. Desalination. 2011; 277(1): 244-9. doi: 10.1016/j.desal.2011.04.033.

11. Haghighat GA, Dehghani MH, Nasseri S, Mahvi AH, Rastkari N. Comparison of carbon nonotubes and activated alumina efficiencies in fluoride removal from drinking water. Indian J Sci Technol 2012; 5(S3): 2432-5.

12. Malakootian M, Moosazadeh M, Yousefi N, Fatehizadeh A. Flouride removal from aqueous solution by pumice casestudy on Kuhbonan water. Afr J Environ Sci Tech 2011; 5(4): 299-306. doi: 10.5897/AJEST10.308.

13. Dou X, Mohan D, Pittman CU, Yang S. Remediating fluoride from water using hydrous zirconium oxide. Chem Eng J 2012; 198-199: 236-45. doi: 10.1016/j.cej.2012.05.084.

14. Chidambaram S, Ramanathan AL, Vasudevan S. Fluoride 
removal studies in water using natural materials: technical note. Water SA 2003; 29(3): 339-44. doi: 10.4314/wsa. v29i3.4936.

15. Sajidu S, Kayira C, Masamba W, Mwatseteza J. Defluoridation of Groundwater Using Raw Bauxite: Rural Domestic Defluoridation Technology. Environment and Natural Resources Research 2012; 2(3): 1-9. doi: 10.5539/ enrr.v2n3p1.

16. Fan X, Parker DJ, Smith MD. Adsorption kinetics of fluoride on low cost materials. Water Res 2003; 37(20): 4929-37. doi: 10.1016/j.watres.2003.08.014.

17. Xu X, Li Q, Cui H, Pang J, Sun L, An H, et al. Adsorption of fluoride from aqueous solution on magnesia-loaded fly ash cenospheres. Desalination 2011; 272(1): 233-9. doi: 10.1016/j.desal.2011.01.028.

18. Çengeloğlu Y, Kır E, Ersöz M. Removal of fluoride from aqueous solution by using red mud. Sep Purif Technol 2002; 28(1): 81-86. doi: 10.1016/S1383-5866(02)00016-3.

19. Ma Y, Shi F, Zheng X, Ma J, Gao C. Removal of fluoride from aqueous solution using granular acid-treated bentonite (GHB): batch and column studies. J Hazard Mater 2011; 185(2-3): 1073-80. doi: 10.1016/j.jhazmat.2010.10.016.

20. Lavecchia R, Medici F, Piga L, Rinaldi G, Zuorro A. Fluoride Removal from Water by Adsorption on a High Alumina Content Bauxite. Chem Eng Trans 2012; 26: 225-30. doi: 10.3303/CET1226038.

21. Bhakat PB, Gupta AK, Ayoob S, Kundu S. Investigations on arsenic $(\mathrm{V})$ removal by modified calcined bauxite. Colloids Surf A Physicochem Eng Asp 2006; 281(1-3): 237-45. doi: 10.1016/j.colsurfa.2006.02.045.

22. Baral SS, Das SN, Rath P, Chaudhury GR. Chromium(VI) removal by calcined bauxite. Biochem Eng J 2007; 34(1): 69-75. doi: 10.1016/j.bej.2006.11.019.

23. Debasish M, Debaraj M, Kyung Ho P. A laboratory scale study on $\operatorname{arsenic}(\mathrm{V})$ removal from aqueous medium using calcined bauxite ore. J Environ Sci 2008; 20(6): 683-9. doi: 10.1016/S1001-0742(08)62113-0.

24. Thole B. Defluoridation kinetics of $200^{\circ} \mathrm{C}$ calcined bauxite, gypsum, and magnesite and breakthrough characteristics of their composite filter. J Fluor Chem 2011; 132(8): 529-35. doi: 10.1016/j.jfluchem.2011.05.016.

25. Sajidu SMI, Masamba WRL, Thole B, Mwatseteza JF. Groundwater fluoride levels in villages of Southern Malawi and removal studies using bauxite. Int J Phys Sci 2008; 3(1): 1-11.

26. Atasoy AD, Yesilnacar MI, Sahin MO. Removal of fluoride from contaminated ground water using raw and modified bauxite. Bull Environ Contam Toxicol 2013; 91(5): 595-9. doi: 10.1007/s00128-013-1099-z.

27. Sadeghkasmaei L, Gorgin N, Fekrikohbanani M. Survey the amount of fluoride in Kohbanan (Kerman-Iran) soil and water and them effect on dental health. The First International Conference on Water Crisis; March 10-12, 2013; Zabol University, Zabol; 2013.

28. American Public Health Association. Standard Methods For the Examination of Water and Wastewater. Washington, DC: American Public Health Association; 1998.

29. Peter KH. Defluoridation of high fluoride waters from natural water sources by using soils rich in bauxite and kaolinite. J Eng Appl Sci 2009; 4(4): 240-6.
30. Altundoğan HS, Tümen F. Removal of phosphates from aqueous solutions by using bauxite. I: Effect of $\mathrm{pH}$ on the adsorption of various phosphates. J Chem Technol Biotechnol 2002; 77(1): 77-85. doi: 10.1002/jctb.525.

31. Ayoob S, Gupta AK, Bhakat PB. Analysis of breakthrough developments and modeling of fixed bed adsorption system for As $(\mathrm{V})$ removal from water by modified calcined bauxite (MCB). Sep Purif Technol 2007; 52(3): 430-8. doi: 10.1016/j. seppur.2006.05.021.

32. Malakootian M, Javdan M, Iranmanesh F, Yaghmaeian K. Evaluation of active bauxite mine (Tash) in the removal of fluoride from drinking water: a case study on Kuhbonan water. Journal of Sabzevar University of Medical Sciences 2016; 23(3): 540-9. doi: 10.21859/sums-2303540. [In Persian].

33. Shrivastava BK, Vani A. Comparative study of Defluoridation technologies in India. Asian Journal of Experimental Sciences 2009; 23(1): 269-74.

34. Malakootian M, Fatehizadeh A, Yousefi N, Ahmadian M, Moosazadeh M. Fluoride removal using Regenerated Spent Bleaching Earth (RSBE) from groundwater: Case study on Kuhbonan water. Desalination 2011; 277(1-3): 244-9. doi: 10.1016/j.desal.2011.04.033.

35. Malakootian M, Javdan M, Iranmanesh F. Fluoride Removal Study from Aqueous Solutions using Bauxite Activated Mines in Yazd Province (Case Study: Kuhbanan Water). Journal of Community Health Research 2014; 3(2): 103-14.

36. Malakootian M, Fatehizadeh A, Yousefi N. Evaluating the effectiveness of Modified pumice in fluoride Removal from Water. Asian J chem 2011; 23(8): 3691-4.

37. Gulnaz O, Saygideger S, Kusvuran E. Study of $\mathrm{Cu}(\mathrm{II})$ biosorption by dried activated sludge: effect of physicochemical environment and kinetics study. J Hazard Mater 2005;120(1-3): 193-200. doi: 10.1016/j.jhazmat.2005.01.003.

38. Lv L, He J, Wei M, Evans DG, Duan X. Factors influencing the removal of fluoride from aqueous solution by calcined $\mathrm{Mg}-\mathrm{Al}-\mathrm{CO} 3$ layered double hydroxides. J Hazard Mater 2006; 133(1-3): 119-28. doi: 10.1016/j.jhazmat.2005.10.012.

39. Mohapatra D, Mishra D, Mishra SP, Chaudhury GR, Das RP. Use of oxide minerals to abate fluoride from water. J Colloid Interface Sci 2004; 275(2): 355-9. doi: 10.1016/j. jcis.2004.02.051.

40. Das N, Pattanaik P, Das R. Defluoridation of drinking water using activated titanium rich bauxite. J Colloid Interface Sci 2005; 292(1): 1-10. doi: 10.1016/j.jcis.2005.06.045.

41. Tor A, Danaoglu N, Arslan G, Cengeloglu Y. Removal of fluoride from water by using granular red mud: Batch and column studies. J Hazard Mater 2009; 164(1): 271-8. doi: 10.1016/j.jhazmat.2008.08.011.

42. Wang Y, Chen N, Wei W, Cui J, Wei Z. Enhanced adsorption of fluoride from aqueous solution onto nanosized hydroxyapatite by low-molecular-weight organic acids. Desalination 2011; 276(1-3): 161-8. doi: 10.1016/j. desal.2011.03.033.

43. Malakootian M, Javdan M, Iranmanesh F. Performance evaluation of the removal of fluoride from drinking water using mendon bauxite mine: case study on Kuhbonan Water, Kerman, Iran. Journal of Health System Research 2016; 12(1): 14-20. [In Persian]. 